\title{
Endogenous Prion Protein Attenuates Experimentally Induced Colitis
}

\author{
Gary R. Martin, ${ }^{\star \dagger}$ Catherine M. Keenan, ${ }^{\dagger}$ \\ Keith A. Sharkey, ${ }^{\dagger}$ and Frank R. Jirik* \\ From the Department of Biochemistry and Molecular Biology \\ and the McCaig Institute for Bone and Joint Health," and the \\ Hotchkiss Brain Institute and Snyder Institute of Infection, \\ Immunity, and Inflammation, Department of Physiology and \\ Pharmacology, ${ }^{\dagger}$ University of Calgary, Calgary, Alberta, Canada
}

\begin{abstract}
Although the cellular prion protein $\left(\operatorname{PrP}^{\mathrm{C}}\right)$ is expressed in the enteric nervous system and lamina propria, its function(s) in the gut is unknown. Because $\operatorname{PrP}^{C}$ may exert a cytoprotective effect in response to various physiologic stressors, we hypothesized that $\operatorname{PrP}^{\mathrm{C}}$ expression levels might modulate the severity of experimental colitis. We evaluated the course of dextran sodium sulfate (DSS)induced colitis in hemizygous Tga20 transgenic mice (approximately sevenfold overexpression of $\left.\operatorname{PrP}^{\mathrm{C}}\right), \operatorname{Prnp}^{-1-}$ mice, and wild-type mice. On day 7 , colon length, disease severity, and histologic activity indices were determined. Unlike DSS-treated wild-type and Prnp ${ }^{-/-}$animals, $\operatorname{PrP}^{\mathbf{C}}$ overexpressing mice were resistant to colitis induction, exhibited much milder histopathologic features, and did not exhibit weight loss or colonic shortening. In keeping with these results, pro-survival molecule expression and/or phosphorylation levels were elevated in DSStreated Tga20 mice, whereas pro-inflammatory cytokine production and pSTAT3 levels were reduced. In contrast, DSS-treated Prnp ${ }^{-/-}$mice exhibited increased BAD protein expression and a cytokine expression profile predicted to favor inflammation and differentiation. $\operatorname{PrP}^{\mathrm{C}}$ expression from both the endogenous Prnp locus or the Tga20 transgene was increased in the colons of DSStreated mice. Considered together, these findings demonstrate that $\operatorname{PrP}^{\mathrm{C}}$ has a previously unrecognized cytoprotective and/or anti-inflammatory function within the murine colon. (Am J Pathol 2011, 179:2290-2301; DOI: 10.1016/j.ajpath.2011.07.025)
\end{abstract}

The physiologic functions of the normal cellular prion protein $\left(\mathrm{Pr}^{\mathrm{C}}\right)$ remain poorly understood despite the wellcharacterized role of the misfolded molecule in the pathogenesis of neurodegenerative diseases such as bovine spongiform encephalopathy and Creutzfeldt-Jakob disease. Although mice lacking $\mathrm{PrP}^{\mathrm{C}}$ are viable, ${ }^{1}$ results from studies of transgenic mice either lacking or overexpressing $\operatorname{PrP}^{\mathrm{C}},{ }^{2,3}$ together with the prion gene (Prnp) being highly conserved within vertebrate species, ${ }^{4,5}$ strongly suggest an important role for this protein. Prnp encodes a widely expressed 253-amino acid membrane-anchored glycoprotein that is particularly abundant in the central nervous system and lymphoid organs. ${ }^{4}$ Copper binding to $\mathrm{PrP}^{\mathrm{C}}$ induces endocytosis of the copper-PrPC complex via clathrin-coated pits, implying that $\mathrm{PrP}^{\mathrm{C}}$ is involved in copper homeostasis. ${ }^{6}$ In addition, $\operatorname{PrP}^{\mathrm{C}}$ functions as a cell surface receptor with the capacity to modulate downstream intracellular signaling pathways. ${ }^{7-9}$ In the gut, $\operatorname{PrP}^{\mathrm{C}}$ has been localized to components of the enteric nervous system ${ }^{10,11}$ and gut-associated lymphoid tissue, ${ }^{12}$ and it is also expressed in epithelial cells. ${ }^{13}$

Several lines of evidence suggest a fundamental role for $\mathrm{PrP}^{\mathrm{C}}$ during states of pathophysiologic stress. For example, $\operatorname{PrP}^{C}$ was one of the two most up-regulated proteins during the recovery phase after traumatic brain injury, ${ }^{14}$ and the level of $\mathrm{PrP}^{\mathrm{C}}$ expression is a significant factor not only in determining responses to experimental cerebral ischemia ${ }^{15}$ but also in murine models of Alzheimer's disease. ${ }^{16,17}$ Furthermore, Prnp deficiency exacerbates neuroinflammation during murine experimental autoimmune encephalomylelitis, ${ }^{18,19}$ dysregulates iron and copper homeostasis, ${ }^{20,21}$ and sensitizes cells to ischemia and oxidative stress. ${ }^{3,22}$ Thus, via molecular mechanism(s) that remain ill defined, $\mathrm{PrP}^{\mathrm{C}}$ is able to exert cytoprotective functions.

The pathogenesis of inflammatory bowel disease, a chronic relapsing and remitting disease of the gut that includes both Crohn's disease and ulcerative colitis, remains to be determined. ${ }^{23,24}$ Oxidative stress, destabili-

\footnotetext{
Supported by a grant from Alberta Prion Research Institute, Alberta Innovates-Bio Solutions. F.R.J. held a Canada Research Chair award. K.A.S. is an Alberta Innovates-Health Solutions Medical Scientist and holds the Crohn's and Colitis Foundation of Canada Chair in Inflammatory Bowel Disease Research at the University of Calgary.

Accepted for publication July 13, 2011.

Address reprint requests to: Frank R. Jirik, M.D., F.R.C.P.C., University of Calgary, 3280 Hospital Dr. NW, Calgary, AB, Canada. E-mail: jirik@ucalgary.ca.
} 
zation of host mucosal defenses, and impaired regulation of innate immune responses to nonpathogenic commensal enteric bacteria likely have a role in disease pathogenesis. ${ }^{23}$ Given the distribution and function of $\mathrm{PrP}^{\mathrm{C}}$ in various components of the innate and adaptive immune system and in elements of the enteric nervous system, ${ }^{4,11}$ we postulated a role for this molecule in the pathogenesis of inflammatory bowel disease.

$\mathrm{PrP}^{\mathrm{C}}$ has a number of potential protective roles during the course of inflammatory bowel disease. For example, it has been recently demonstrated that $\mathrm{PrP}^{\mathrm{C}}$ is involved in modulating T-cell activation and proliferation ${ }^{18,25}$ and the phagocytic activity of macrophages. ${ }^{26,27}$ Moreover, depletion of $\mathrm{PrPC}^{\mathrm{C}}$ skews T cells toward the helper T cell type 1 (Th1) and type 17 (Th17) phenotypes. ${ }^{18,19}$ This is of significance because these lineages produce a variety of proinflammatory cytokines that are up-regulated in the intestinal mucosa in individuals with inflammatory bowel disease ${ }^{28}$ Another possibility is that $\mathrm{PrP}^{\mathrm{C}}$ functions as an antimicrobial peptide. Pasupuleti et $\mathrm{a}^{29}$ have demonstrated that intact recombinant $\mathrm{PrP}^{\mathrm{C}}$ has antibacterial activity at normal and low $\mathrm{pH}$ and that synthetic peptides derived from the $\mathrm{N}$-terminal region of $\mathrm{PrP}^{\mathrm{C}}$ are cytotoxic to several bacterial species including Escherichia coli, Pseudomonas aeruginosa, Bacillus subtilis, and Staphylococcus aureus.

Although acute colitis can accelerate the onset of disease after oral challenge with infectious prions, ${ }^{30}$ a physiologic role for $\mathrm{PrPC}^{\mathrm{C}}$ in colitis has not been reported. We, therefore, examined the role of $\mathrm{PrPC}^{\mathrm{C}}$ in mice either lacking or overexpressing this protein in the dextran sulfate sodium (DSS)-induced model of experimental colitis. Although this model does not fully replicate human inflammatory bowel disease, it does share a number of pathologic features with this disease. ${ }^{31,32}$ Because PrPC deficiency exacerbates oxidative stress and neuroinflammation, we hypothesized that $\mathrm{PrP}^{\mathrm{C}}$ might demonstrate protective and/or anti-inflammatory effects in DSS-induced colitis.

\section{Materials and Methods}

\section{Animals}

These studies were conducted in accordance with the guidelines established by the Canadian Council of Animal Care, and all protocols were approved by the Health Sciences Animal Care Committee at the University of Calgary. Male mice matched by age and body weight (20 to $25 \mathrm{~g}$ ) were fed standard laboratory chow, had access to water ad libitum, and were maintained in a barrier unit in a room with controlled temperature $\left(22^{\circ} \mathrm{C} \pm 1^{\circ} \mathrm{C}\right)$, humidity (65\% to $70 \%$ ), and light cycle (12 hours light and 12 hours dark).

Male hemizygous Tga20 mice (approximately sevenfold overexpression of $\mathrm{PrP}^{\mathrm{C}}$ ), ${ }^{33}$ Zurich I Prnp-deficient mice, ${ }^{1}$ and age-matched ( 8 to 10 weeks of age) wild-type (WT) littermates (all on a C57BI/6 background) were administered 3\% DSS in their drinking water for 7 days. A second group was given 3\% DSS for 3 days. Mice were monitored daily to assess fluid consumption, change in body weight, stool consistency and for the presence of gross blood in the feces.

\section{Disease Activity Index}

Mice were euthanized at day 3 or 7 after initiation of treatment using DSS or tap water, and their colons were quickly removed. The severity of colitis was assessed using an established Disease Activity Index (DAI) demonstrated to be relatively representative of clinical measures for assessment of inflammatory bowel disease. ${ }^{34}$ The DAI score was derived as follows: for weight loss, $0=$ none, $1=1 \%$ to $5 \%, 2=5 \%$ to $10 \%, 3=10 \%$ to $15 \%$, and $4=$ greater than $15 \%$; for stool consistency, $0=$ normal, 2 = loose, and $4=$ watery diarrhea; and for colonic bleeding, 0 = none, 2 = slight, and $4=$ gross . The scores were added to produce a DAI ranging from 0 (unaffected) to 12 (severe colitis).

\section{Histologic Activity Index}

Colonic samples (3 to $4 \mathrm{~cm}$ distal to the cecum) were fixed in $10 \%$ neutral buffered formalin, embedded in paraffin, and stained using either H\&E or periodic acidSchiff. Damage was assessed using a previously described histologic activity index (HAl), ${ }^{34}$ as follows: for epithelial damage, $0=$ none, $1=$ minimal loss of goblet cells, 2 = extensive loss of goblet cells, $3=$ loss of crypt cells and extensive loss of goblet cells, and $4=$ extensive loss of crypt cells and goblet cells; and for infiltration, $0=$ none, 1 = crypt base, 2 = muscularis mucosa, $3=$ extensive muscularis mucosa and edema, and 4 = submucosal.

\section{Intestinal Permeability}

Intestinal permeability was determined in healthy untreated mice by measuring levels of plasma fluorescein isothiocyanate (FITC)-labeled dextran ${ }^{35}$ after administration via gavage of $60 \mathrm{mg} / 100 \mathrm{~g}$ body weight of FITCconjugated dextran (average molecular mass $4000 \mathrm{Da}$; Sigma-Aldrich Corp., St. Louis, MO) in PBS (pH 7.4). Blood was obtained by cardiac puncture 4 hours after administration of FITC-conjugated dextran and centrifuged for 10 minutes ( $5000 \mathrm{rpm}$ at $4^{\circ} \mathrm{C}$ ). The plasma ( $100 \mu \mathrm{L}$ ) was added to a 96-well dark microplate, and the concentration of fluorescein was determined using spectrophotofluorometry (Fluoroskan Ascent; Thermo LabSystems, Inc., Beverly, MA) with an excitation wavelength of $485 \mathrm{~nm}$ and an emission wavelength of $527 \mathrm{~nm}$, using serially diluted samples of the marker as standard.

\section{Immunoblotting}

To determine $\operatorname{PrP}^{\mathrm{C}}$ expression, colonic homogenates (10\% $\mathrm{w} / \mathrm{v})$ were prepared in extraction buffer $(0.15 \mathrm{mmol} / \mathrm{L} \mathrm{NaCl}$, $5 \mathrm{mmol} / \mathrm{L}$ EDTA, $1 \%$ Triton-X 100, $10 \mathrm{mmol} / \mathrm{L}$ Tris- $\mathrm{HCl}[\mathrm{pH}$ 7.4]) with the addition of a protease inhibitor cocktail (Complete; Roche Diagnostics GmbH, Mannheim, Germany). Protein concentrations were determined using the Bradford 
assay. Proteins $(30 \mu \mathrm{g})$ were separated on $12 \%$ SDS-polyacrylamide gels and transferred onto polyvinylidene difluoride membranes. Lysates were prepared from mouse brain for use as a quality control measure. Membranes were blocked in 5\% skim milk-TBST (Tris-buffered saline and Tween 20) and incubated with anti-PrP monoclonal antibodies SAF-32 (1:4000 dilution; Cayman Chemical Co., Inc., Ann Arbor, MI) or BAR-221 (1:4000 dilution; SPlbio, BioNovus Life Sciences, Cherrybrook, NSW, Australia) for 24 hours at $4^{\circ} \mathrm{C}$. For determination of $\mathrm{PrP}^{\mathrm{C}}$ expression in the colon, the primary antibody used was SAF-32. A horseradish peroxidase-conjugated sheep anti-mouse secondary antibody was used. Bands were visualized using a chemiluminescence substrate (SuperSignal West Pico; Thermo Scientific Pierce Protein Research Products, Rockford, IL), and densities were assessed using a calibrated imaging densitometer equipped with Quantity One software (BioRad, Mississauga, ON, Canada). Filters were then stripped and re-probed using an anti- $\beta$-actin antibody (Sigma-Aldrich Corp.).

To determine pro-survival and pro-apoptotic signaling molecule expression, methods were duplicated as described above with modifications. Proteins $(50 \mu \mathrm{g})$ from each sample were separated on 10\% SDS-polyacrylamide gels, and after transfer, membranes were blocked in 5\% skim milk-TBST, washed three times in TBST, and incubated overnight at $4{ }^{\circ} \mathrm{C}$ in $5 \%$ bovine serum albumin with the polyclonal antibodies p44/42 (1:1000), phosphop44/42 (1:500), phospho-Akt (1:500), phospho-STAT3 (1: 500), p38 (1:1000), and phospho-p38 (all from Cell Signaling Technology, Inc., Beverly, MA).

\section{Immunohistochemistry}

The mouse colons ( 3 to $4 \mathrm{~cm}$ distal to the cecum) were removed, opened along the midline, and placed in PBS containing $1 \mu \mathrm{mol} / \mathrm{L}$ nifedipine to fully relax the smooth muscle. After 5 minutes, these segments were pinned flat, fixed in $10 \%$ formalin for 48 hours, embedded in paraffin, and sectioned ( $6 \mu \mathrm{mol} / \mathrm{L})$. After deparaffinization in xylene and rehydration in graded ethanol, endogenous peroxidase activity was blocked via incubation with $3 \%$ hydrogen peroxide. Tissue sections were then heated at $100^{\circ} \mathrm{C}$ in $10 \mathrm{mmol} / \mathrm{L}$ citrate buffer $(\mathrm{pH}$ 6.0) to retrieve antigens, and were preincubated with normal goat serum (10\%). The primary antibody used for $\operatorname{PrP}^{\mathrm{C}}$ staining was mouse monoclonal anti-SAF-32 (1:500; overnight incubation at $4^{\circ} \mathrm{C}$; Cayman Chemical Co., Inc.), and the secondary antibody used was donkey anti-mouse CY3 antibody (1:100; Jackson ImmunoResearch Laboratories, Inc., West Grove, PA). The tissues were subsequently mounted and visualized using an Axiolmager A2 fluorescence microscope in conjunction with an AxioCam MR3 digital monochrome camera and AxioVision 4 LE software (all from Carl Zeiss Microlmaging GmbH, Göttingen, Germany). Micrographs (40X magnification) were obtained under identical conditions.
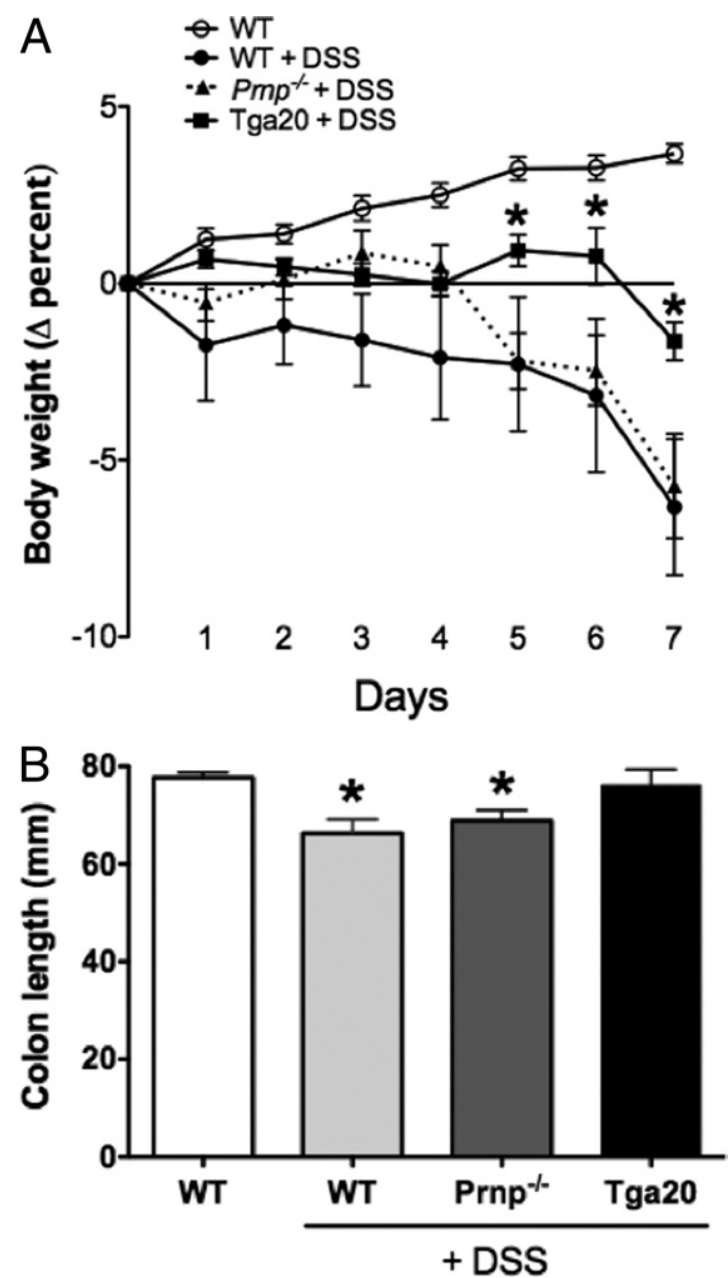

Figure 1. Overexpression of $\mathrm{PrP}^{\mathrm{C}}$ reduced weight loss and colonic shortening during DSS-induced colitis. A: All mice receiving DSS demonstrated significant reductions in body weight when compared with mice given tap water. However, weight loss was attenuated in mice that overexpressed $\operatorname{PrP}^{\mathrm{C}}$ $\left({ }^{*} P<0.05\right.$ versus DSS-treated $P r n p^{-/-}$and WT mice). B: Treatment with DSS for 7 days induced colonic shortening in $P_{r n P^{-1}}$ and WT mice but not in Tga20 mice ( ${ }^{*} P<0.05$ for untreated WT or DSS-treated Tga20 mice relative to DSS-treated $\operatorname{Prnp}^{-1-}$ and WT mice). Given are mean \pm SE values in seven or more mice.

\section{RNA Extraction and Analysis}

Real-time RT-PCR was used to examine transcriptional changes of several cytokines, as well as regulators of cytokine expression that have demonstrated a role in colitis. These genes included $\|1 \mathrm{~b}\| 6,,\|10\| ,17 \mathrm{~A}$, Tgfb, Tnfa, Ifng, Socs3 and Nos2. Colonic tissues from control and DSS-treated mice were placed in TRIzol reagent (Gibco-BRL, Invitrogen Corp., Carlsbad, CA), and total cellular RNA was extracted according to the manufacturer's instructions. First-strand cDNA was synthesized from $2 \mu \mathrm{g}$ total RNA in a $25-\mu \mathrm{L}$ reaction volume. Duplicate independent quantitative real-time PCR was performed using the LightCycler System (Roche Diagnostics GmbH). SYBR Green I (Roche Diagnostics $\mathrm{GmbH}$ ) was used to visualize and monitor the amplified product in real time. Gene-specific oligonucleotide primers were designed for the genes of interest. $\beta$-Actin was amplified as an internal control. The change in fluorescence of SYBR 

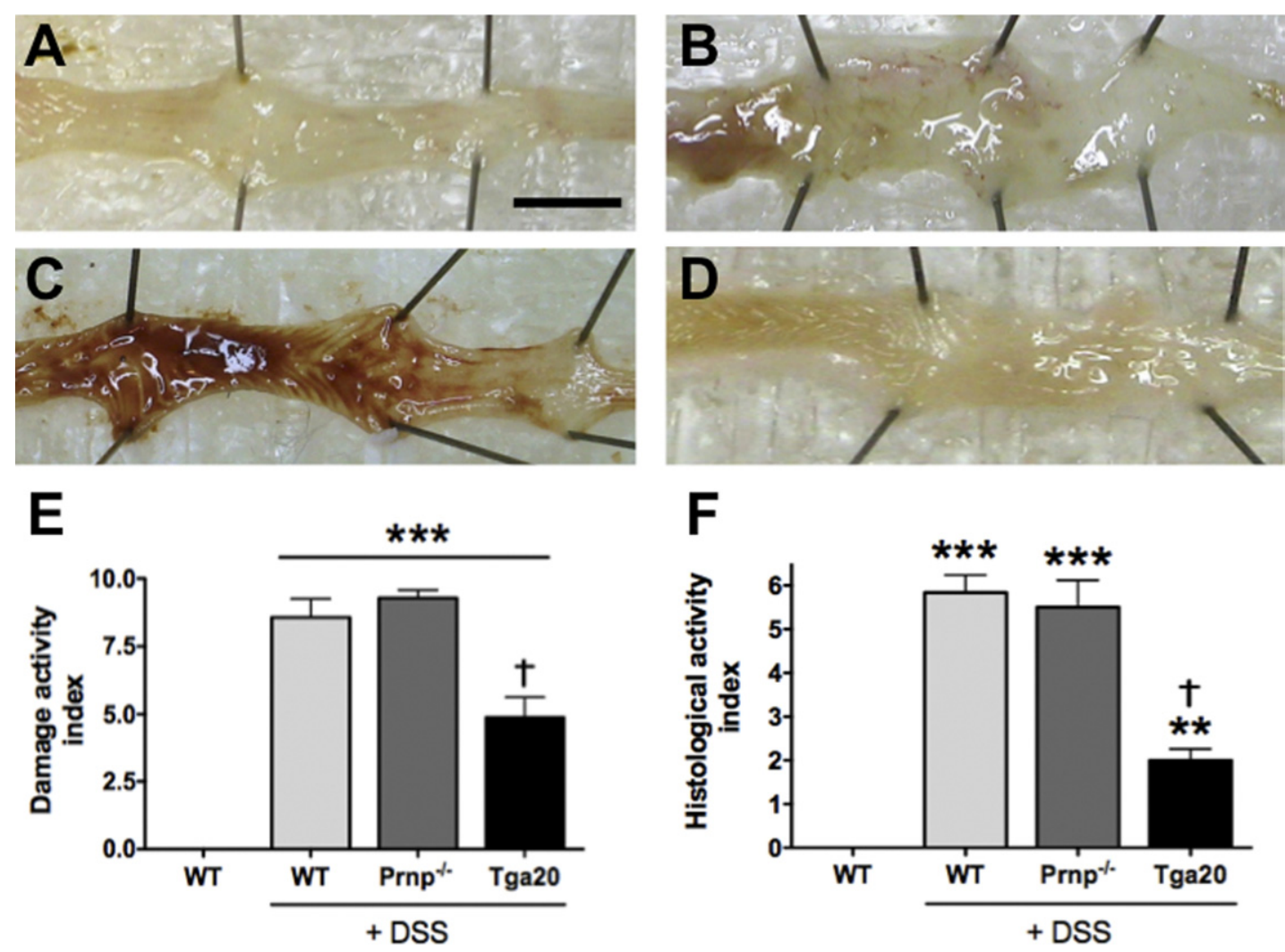

Figure 2. Overexpression of $\mathrm{PrP}^{\mathrm{C}}$ reduced colonic damage in DSS-treated mice. Mice were treated with either 3\% DSS or tap water for 7 days. A: No DSS - tap water only. Representative images of colonic tissue damage induced by DSS treatment in WT (B), Prnp ${ }^{-1}$ (C), or Tga20 (D) mice. E: Clinical assessment of colitis using a DAI based on stool consistency, bleeding, and weight loss. DSS treatment increased DAI scores in all groups when compared with control mice given tap water $\left({ }^{* * * * *} P<0.001\right)$. However, the DAI in DSS-treated Tga20 mice was significantly reduced when compared with both DSS-treated Prnp ${ }^{-1-}$ and WT mice $(P<0.01)$. Given are mean \pm SE values in seven or more mice. F: Although the HAI in all mice receiving DSS was elevated $(* * * P<0.001 ; * * P<0.01$ versus untreated DSS group), colonic damage in Tga20 mice was markedly reduced $(P<0.01)$. Given are mean \pm SE values in six or more mice. Scale bar $=1 \mathrm{~cm}$.

Green I dye in each cycle was determined using the LightCycler system software (Roche Diagnostics $\mathrm{GmbH}$ ), and the threshold cycle above background for each reaction was calculated. The $\mathrm{Ct}$ value of $\beta$-actin was subtracted from that of the gene of interest to obtain a Ct value. The Ct value of an arbitrary calibrator (eg, WT control group) was subtracted from the Ct value of each sample to obtain a $\mathrm{Ct}$ value. The transcription level relative to the calibrator was expressed as $2^{-\mathrm{Ct}}$.

\section{Real-Time Primer Sequences}

Primers used were $\beta$-actin (forward, 5'-AGAGGGAAATCGTGCGTGAC-3'; reverse, 5'-CAATAGTGATGACCTGGCCGT-3'), IFN- $\gamma$ (forward, 5' -TCAAGTGGCATAGATGTGGAAGAA-3'; reverse, 5'-TGGCTCTGCAGGATITCATG-3'), iNOS (forward, 5'-CAGCTGGGCTGTACAAACCTT-3'; reverse, 5'CATTGGAAGTGAAGCGTTCG-3'), IL-1 $\beta$ (forward, 5'-CAACCAACAAGTGATATTCTCCATG-3'; reverse, 5'-GATCCACACTCTCCAGCTGCA-3'), IL-6 (forward, 5'-TCCAGTTGCCTTCTTGGGAC-3'; reverse, 5'-GTGTAATTAAGCCTCCGACTTG-3'), IL-10 (forward, 5'-GGTTGCCAAGCCTTATCGGA-3'; reverse, 5'-ACCTGCTCCACTGCCTTGCT-3'), IL-17 (forward, 5'-GAAGCTCAGTGCCGCCA-3'; reverse, 5'-TTCATGTGGTGGTCCAGCTा-3'), SOCS3 (forward, 5'-GGGTGGCAAAGAAAAGGAG-3'; reverse, 5'-GTTGAGCGTCAAGAC-
CCAGT-3'), TGF- $\beta$ (forward, 5'-TGACGTCACTGGAGTTGTACGG-3'; reverse, 5'-GGTTCATGTCATGGATGGTGC-3'), and TNF- $\alpha$ (forward, 5'-CATCTTCTCAAAATTCGAGTGACAA-3'; reverse, 5'-TGGGAGTAGACAAGGTACAAC CC-3').

\section{Statistical Analysis}

Results are expressed as mean \pm SE. Comparisons among groups of data were made using one-way analysis of variance followed by a post hoc Tukey's test. $P<0.05$ was considered significant.

\section{Results}

\section{PrPC Overexpression Attenuates DSS-Induced Weight Loss and Colonic Shortening}

Treatment with DSS significantly reduced body weight in all groups when compared with untreated mice (Figure 1A). However, weight loss was decreased at 5 to 7 days after initiation of treatment in $\mathrm{PrP}^{\mathrm{C}}$ overexpressing mice when compared with either Prnp ${ }^{-1-}$ or WT mice. These overexpressing mice also demonstrated attenuation of colonic shortening when compared with Prnp ${ }^{-/-}$or WT mice (Figure 1B). 


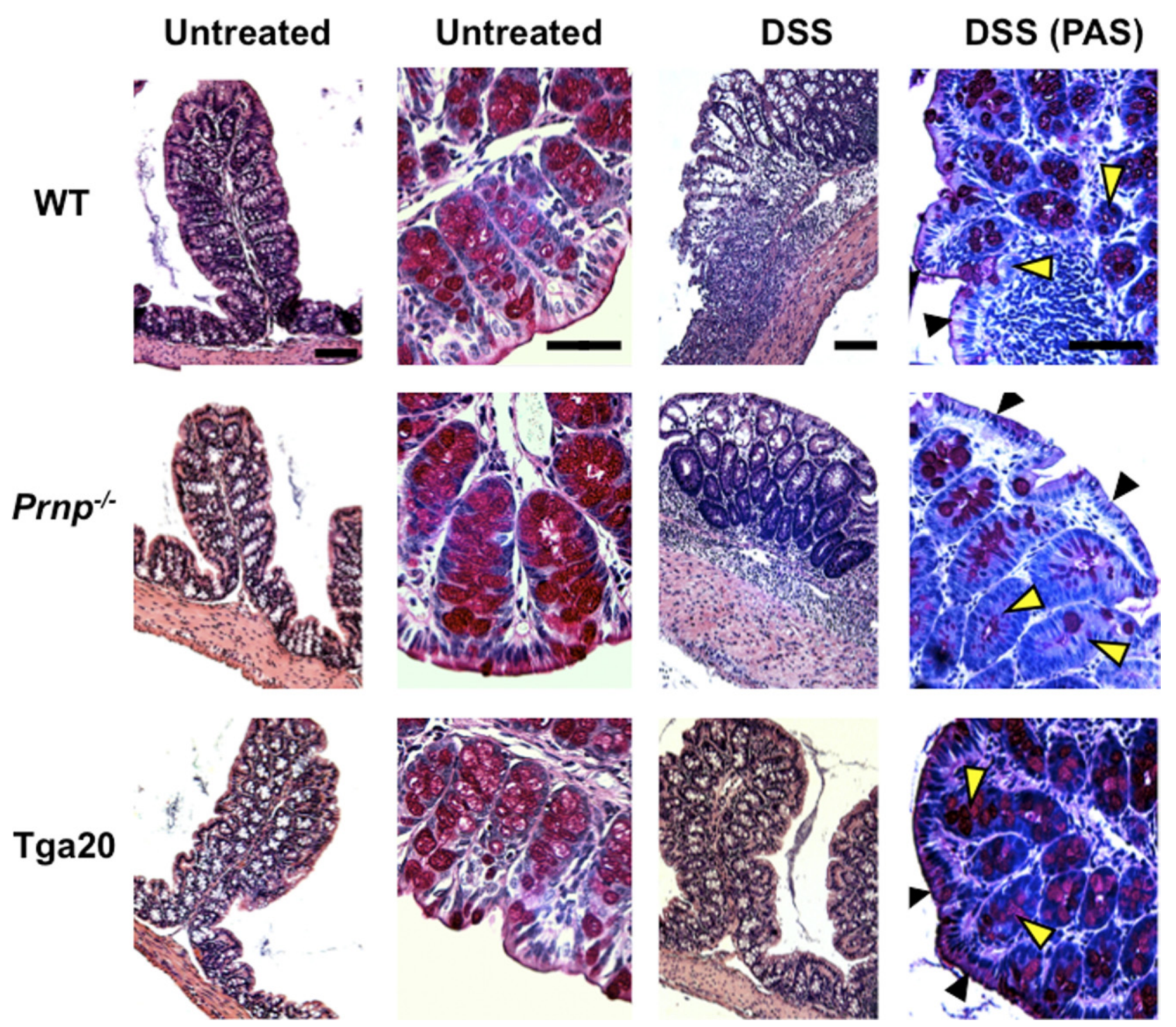

Figure 3. Histologic damage is reduced in colonic tissues of DSS-treated Tga20 mice. H\&E staining was used to visualize colonic samples from healthy and DSS-treated mice. No histologic abnormalities were observed in untreated mice (left panels). With DSS treatment, epithelial damage, depicted by loss of goblet cells, crypt cells, and brush border, was exacerbated in WT and Prnp ${ }^{-1-}$ mice as compared with Tga20 mice. In addition, infiltration was reduced in Tga20 mice as compared with the other groups. Periodic acid-Schiff staining of sections from DSS-treated mice revealed preservation of colonic brush border (black arrowheads) and goblet cells (yellow arrowheads) in Tga20 mice as compared with WT and Prnp ${ }^{-1-}$ mice. Scale bar $=100 \mu \mathrm{m}$.

\section{$\operatorname{PrP}^{C}$ Overexpression Reduces Damage during DSS-Induced Colitis}

Colonic morphologic damage induced by DSS was markedly reduced in mice that overexpressed $\mathrm{PrP}^{\mathrm{C}}$ (Figure 2, A-D). DSS treatment increased colonic damage in all groups when compared with control mice given tap water, however, DAls from Tga20 mice were significantly reduced relative to $\mathrm{Prnp}^{-1-}$ or WT mice (Figure 2E). Although there were elevations in HAls in all mice receiving DSS, the degree of damage in mice that overexpressed $\mathrm{PrP}^{\mathrm{C}}$ was decreased relative to WT or Prnp ${ }^{-1-}$ mice (Figure 2F). In healthy colonic tissue, DAI and HAl values for $P m p^{-/-}$and Tga20 mice were identical to those for healthy WT mice (data not shown). No structural colonic abnormalities were observed among the various groups of healthy mice (Figure 3). However, there were marked reductions in DSS-induced colonic epithelial damage and crypt cell loss in Tga20 mice relative to similarly treated WT and Prmp ${ }^{-1-}$ mice (Figure 3). Moreover, leukocyte infiltration, muscle thickening, and edema were markedly reduced in Tga20 mice when compared with either $\mathrm{Prnp}^{-1-}$ or WT mice. Periodic acid-Schiff staining revealed that brush border membrane and goblets cell losses were attenuated in the colonic tissues of DSS-treated Tga20 mice when compared with similarly treated WT and Prnp ${ }^{-1-}$ mice. These losses of brush border membrane and goblet cells seemed to be exacerbated in Prnp-deficient mice.

\section{$\operatorname{Pr}^{C}$ Expression Is Increased during} DSS-Induced Colitis

Immunoblotting was performed to determine the levels of $\mathrm{PrP}^{\mathrm{C}}$ expression in the colon of WT, $\mathrm{Prnp}^{-/-}$, and Tga20 


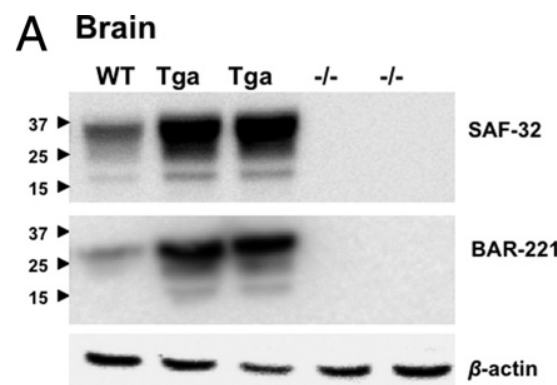

\section{B Colon: Untreated}

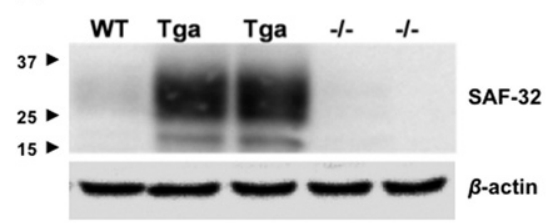

\section{Colon: DSS-treated}

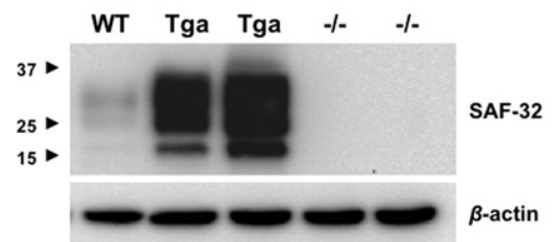

Figure 4. Colonic $\operatorname{PrP}^{\mathrm{C}}$ expression is increased in DSS-treated mice. A: $\operatorname{PrP}^{\mathrm{C}}$ expression as determined via SAF-32 and BAR 221 antibody staining in brain tissues from untreated WT, Prnp ${ }^{-/-}$, and Tga20 mice. B: $\operatorname{PrP}^{\mathrm{C}}$ expression (anti-PrP monoclonal SAF-32) in colonic tissues of untreated WT, Prnp and Tga20 mice. $\mathrm{PrP}^{\mathrm{C}}$ levels in the colon of Tga20 mice were greater (7.4-fold) as compared with those in WT mice. C: DSS-induced colitis led to increased $\mathrm{PrP}^{\mathrm{C}}$ expression from both the endogenous locus (1.4-fold relative to WT mice) and the Tga20 transgene (10.7-fold compared with WT mice, and 1.6-fold relative to untreated Tga 20 mice). $\beta$-Actin was used as the lane loading control for all immunoblot analyses.

mice, both before and after induction of colitis. Initially, $\operatorname{PrP}^{\mathrm{C}}$ expression was verified using brain lysates as a positive control and immunoblotting with two different antibodies: SAF-32, which recognizes an epitope within the octarepeat region, and BAR-221, which recognizes an epitope located in the C-terminus (Figure 4A). In healthy mice, $\mathrm{PrP}^{\mathrm{C}}$ levels were significantly greater in $\mathrm{Prnp}^{+/+}$Tga20 mice (7.4-fold increase relative to untreated WT mice) and absent in colonic tissues of the prion-deficient mice (Figure 4B). In contrast, mice treated with DSS exhibited marked elevations in $\mathrm{PrP}^{\mathrm{C}}$ expression, both from the endogenous locus (1.4-fold increase relative to WT mice) and the Tga20 transgene (10.7-fold increase compared with WT mice, and 1.6-fold increase relative to untreated Tga20 mice) (Figure 4C).

Using immunohistochemistry, we next evaluated $\mathrm{PrP}^{\mathrm{C}}$ expression both before and during DSS-induced colitis. $\mathrm{PrP}^{\mathrm{C}}$ expression was evident in the colonic tissue of healthy WT mice (Figure 5A), and, as expected, was not detectable in tissue from Prnp $^{-1-}$ mice (data not shown). Although signals were higher in the Tga20 samples, the tissue pattern of $\mathrm{PrP}^{\mathrm{C}}$ expression was similar in colons of vehicle-treated WT and Tga20 mice (data not shown). $\mathrm{PrP}^{\mathrm{C}}$ immunoreactivity was localized to various levels of the gut including the myenteric plexus, nerve processes, and circular smooth muscle. Consistent with previous reports, ${ }^{10,36}$ we also observed high levels of $\mathrm{PrPC}^{\mathrm{C}}$ immunoreactivity in sites within the mucosa, which were suggestive of enteroendocrine cells. Moreover, in all of these mentioned regions, colonic inflammation markedly increased the intensity of $\mathrm{PrP}^{\mathrm{C}}$ immunoreactivity in both WT (Figure 5B) and Tga20 (Figure 5D) mice. As expected, PrPC was not detected in DSS-treated $\mathrm{Prnp}^{-1-}$ mice (Figure 5C). There was thickening of the circular muscle layer in the colonic samples from WT mice, and this was increased in the colons of DSS-treated Prnp ${ }^{-/-}$mice.

\section{$\operatorname{PrP}^{C}$ Expression Does Not Affect Intestinal Permeability in Untreated Mice}

Basal intestinal permeability, possibly regulated by the presence or absence of $\mathrm{PrP}^{\mathrm{C}}$, could have led to either increased or decreased access to enteric bacterial anti-
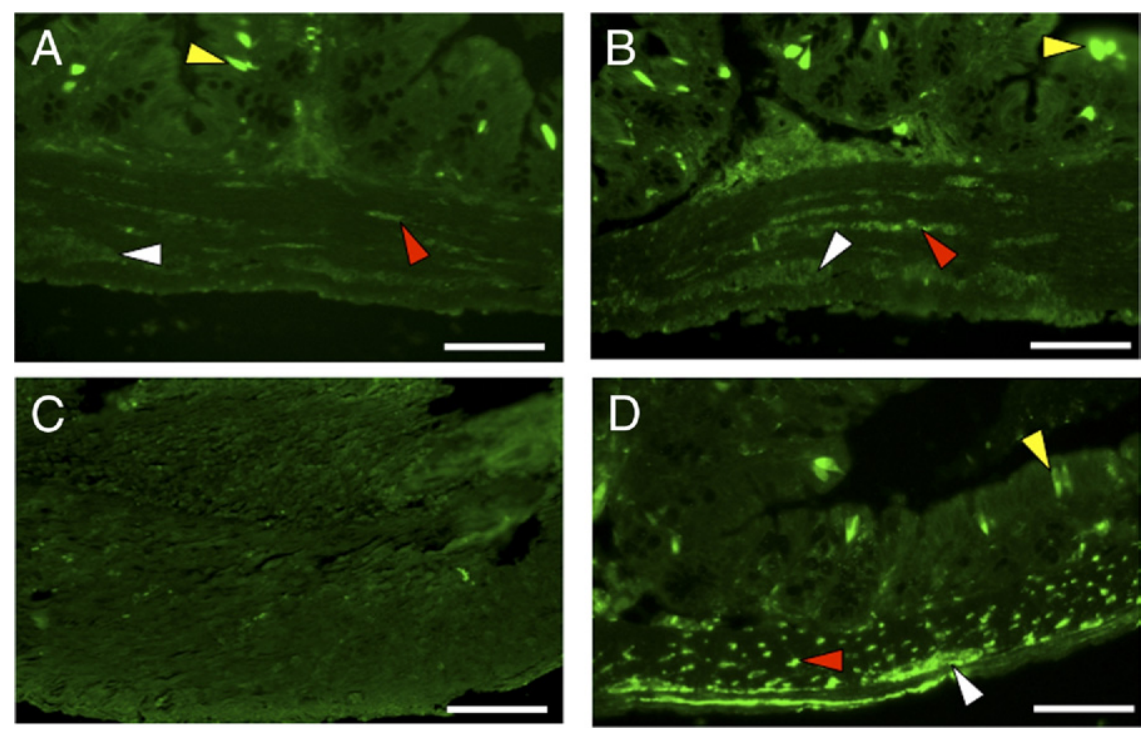

Figure 5. Immunohistochemical localization or $\mathrm{PrP}^{\mathrm{C}}$ in DSS-induced colitis. A: $\operatorname{PrP}^{\mathrm{C}}$ expression was evident in the colonic tissues of healthy WT mice. Prion protein was not detectable in Prnp $^{-1-}$ tissues, but was localized in a similar fashion when vehicle-treated WT and Tga20 mice samples were compared (data not shown). The colonic inflammation induced by DSS in creased $\operatorname{PrP}^{\mathrm{C}}$ immunoreactivity intensity in both WT (B) and Tga20 (D) mice. C: $\operatorname{PrP}^{\mathrm{C}}$ was not detected in DSS-treated Prnp ${ }^{-1-}$ mice. In WT and Tga 20 mice, prion protein was localized to regions within the gut, consistent with the myenteric plexus (white arrowheads), enteroendocrine cells (yellow arrowheads), and nerve processes in the circular smooth muscle layer (red arrowheads). Note thickening of the circular muscle layer in the colonic samples from WT and Prnp ${ }^{-1-}$ mice. Scale bars $=100 \mu \mathrm{M}$. 
A
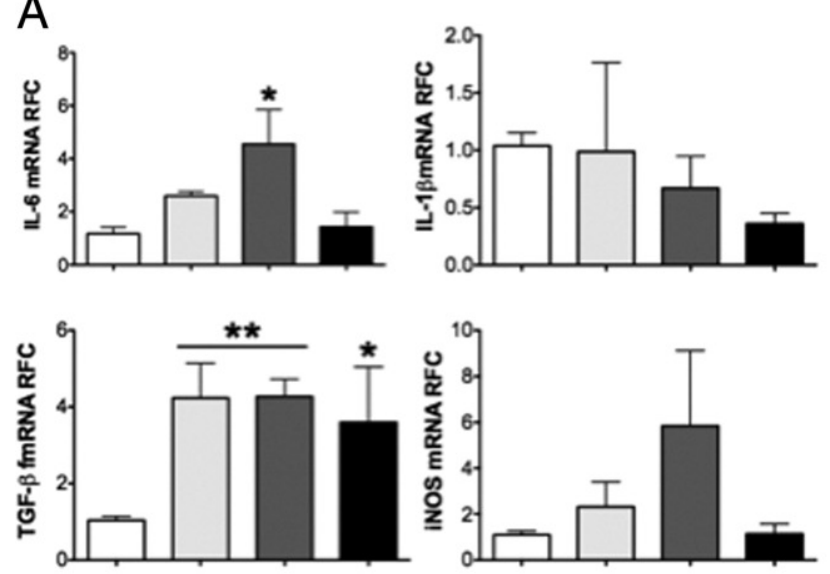

B
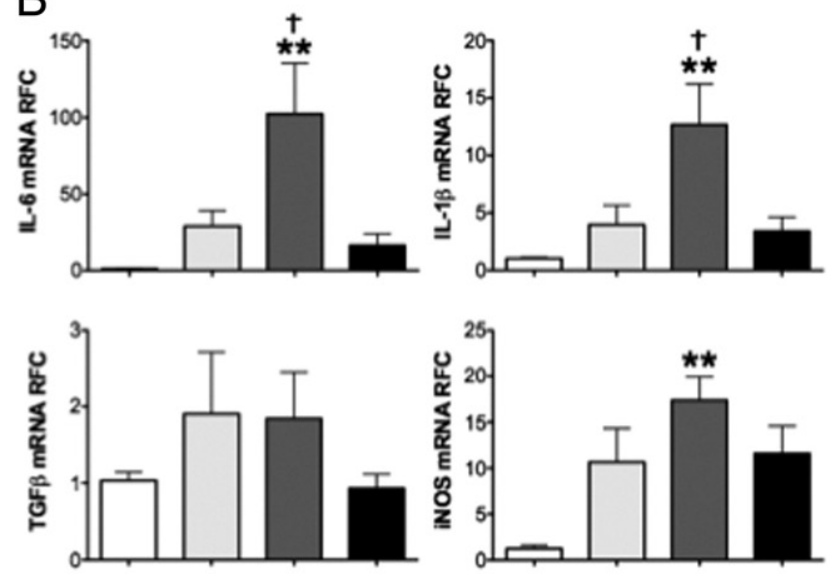
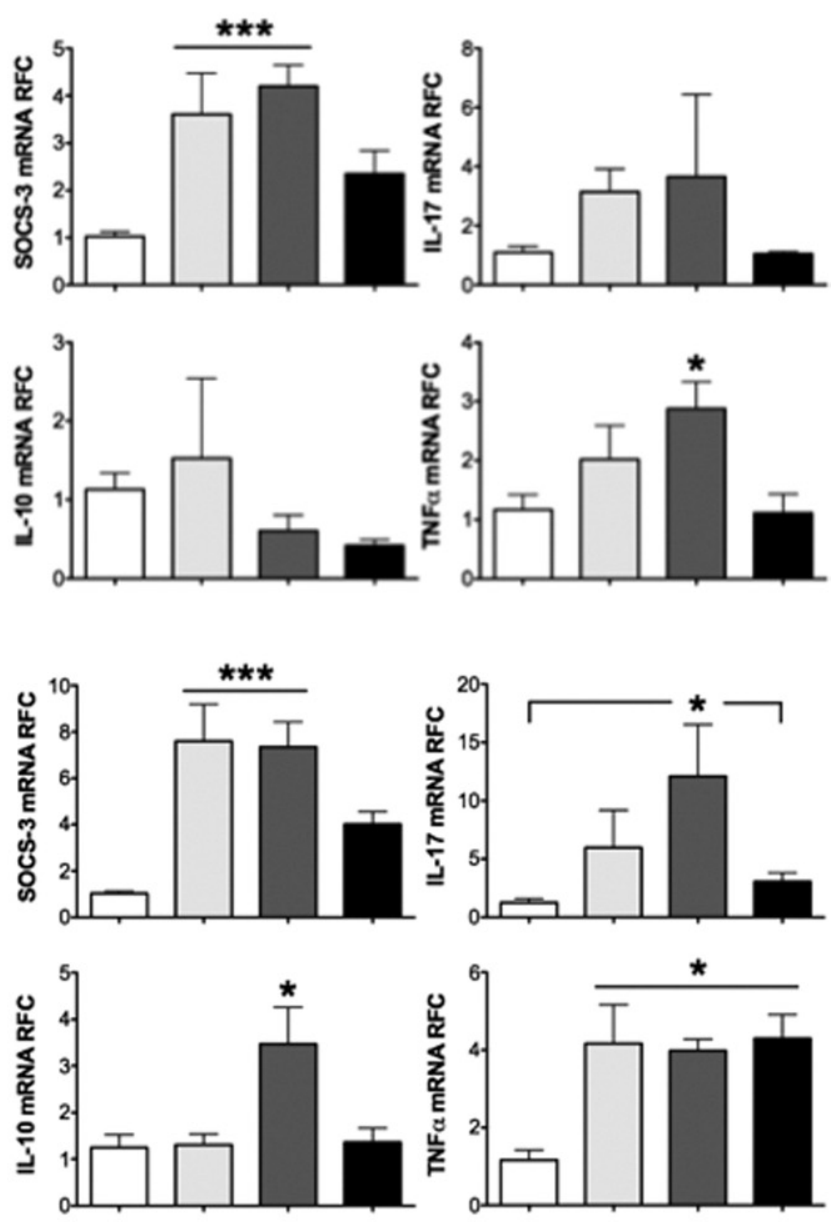

\section{$\square$ WT $\square$ WT + DSS $\square \mathrm{Pmp}^{-1-}+$ DSS $\square$ Tga20 + DSS}

Figure 6. $\mathrm{PrP}^{\mathrm{C}}$ deficiency promotes proinflammatory cytokine transcript expression during colitis. A: Cytokine expression on day 3 of DSS administration. IL-6, TNF- $\alpha$, and SOCS3 expression were elevated in colonic tissues of $\mathrm{PrP}^{\mathrm{C}}$-deficient mice relative to untreated mice. Moreover, colonic expression of IL- 6 and TNF- $\alpha$ was increased in Prnp ${ }^{-1-}$ mice compared with similarly treated Tga 20 mice. TGF- $\beta$ expression was increased in DSS-treated groups relative to untreated mice. B: After 7 days of treatment using DSS, $P_{m} p^{-1-}$ mice demonstrated significantly elevated expression of IL-6, IL-1 $\beta$, SOCS3, IL-17, iNOS, IL-10, and TNF- $\alpha$ relative to untreated WT mice. In addition, colonic tissue IL-6, IL-1 $\beta$, and IL-17 levels in Prnp-deficient mice were increased as compared with those in Tga20 mice. RFC, relative fold-change. Bars represent the mean \pm SE values of four or more mice (day 3 ) or seven or more mice $\left(\right.$ day 7 ). ${ }^{*} P<0.05,{ }^{* *} P<0.01,{ }^{* * * *} P<0.001$ versus untreated WT mice; ${ }^{t} P<0.01$ versus Tga20 mice.

gens. To test whether there were differences in barrier function, healthy untreated WT, Tga20, or Prnp ${ }^{-1-}$ mice underwent gavage using FITC-conjugated dextran. Plasma concentrations of fluorescein, which provided an index of the degree of gut permeability, suggested that there were no differences in gut permeability between the animal groups before DSS treatment: WT, $621.3 \pm 95.7$ $\mathrm{nmol} / \mathrm{L} ;$ Prnp $^{-/-}, 516 \pm 38.5 \mathrm{nmol} / \mathrm{L} ;$ and Tga20, $521.5 \pm$ $27.6 \mathrm{nmol} / \mathrm{L}$ ( $n=4$ or more mice in each group).

\section{$\operatorname{Pr}^{C}$ Modulates Proinflammatory Cytokine}

\section{Expression in DSS-Treated Mice}

Having established that $\operatorname{PrP}^{\mathrm{C}}$ expression influences the degree of damage induced by DSS, we next examined whether altered proinflammatory cytokine expression was involved to explain this effect. By day 3, IL-6, TNF- $\alpha$, and SOCS3 transcripts in the colonic tissues of DSS-treated Prnp ${ }^{-1-}$ mice were significantly elevated as compared with those in untreated mice (Figure 6A). Moreover, IL-6 and TNF- $\alpha$ levels in Prnp ${ }^{-1-}$ mice were increased when compared with levels in similarly treated Tga20 mice. In Prnp ${ }^{-/-}$mice treated with DSS for 7 days, there were marked increases in iNOS transcripts and in transcripts encoding several cytokines including IL-6, IL-1 $\beta$, SOCS3, IL-17, IL-10, and TNF- $\alpha$ (Figure 6B). In particular, colonic RNA transcripts for IL-6, IL-1 $\beta$, and IL-17 in Prnp-deficient mice were markedly increased relative to Tga20 mice. There were no differences in cytokine expression transcripts in colonic tissue samples from healthy untreated Prnp ${ }^{-1-}$, WT, or Tga20 mice (data not shown).

\section{PrPC Affects Pro-Survival and Pro-Apoptotic \\ Molecule Expression}

Inasmuch as the presence or absence of $\mathrm{PrP}^{\mathrm{C}}$ had the potential to regulate a variety of cell-signal transduction pathways, and finding that DSS-induced colitis markedly 
A

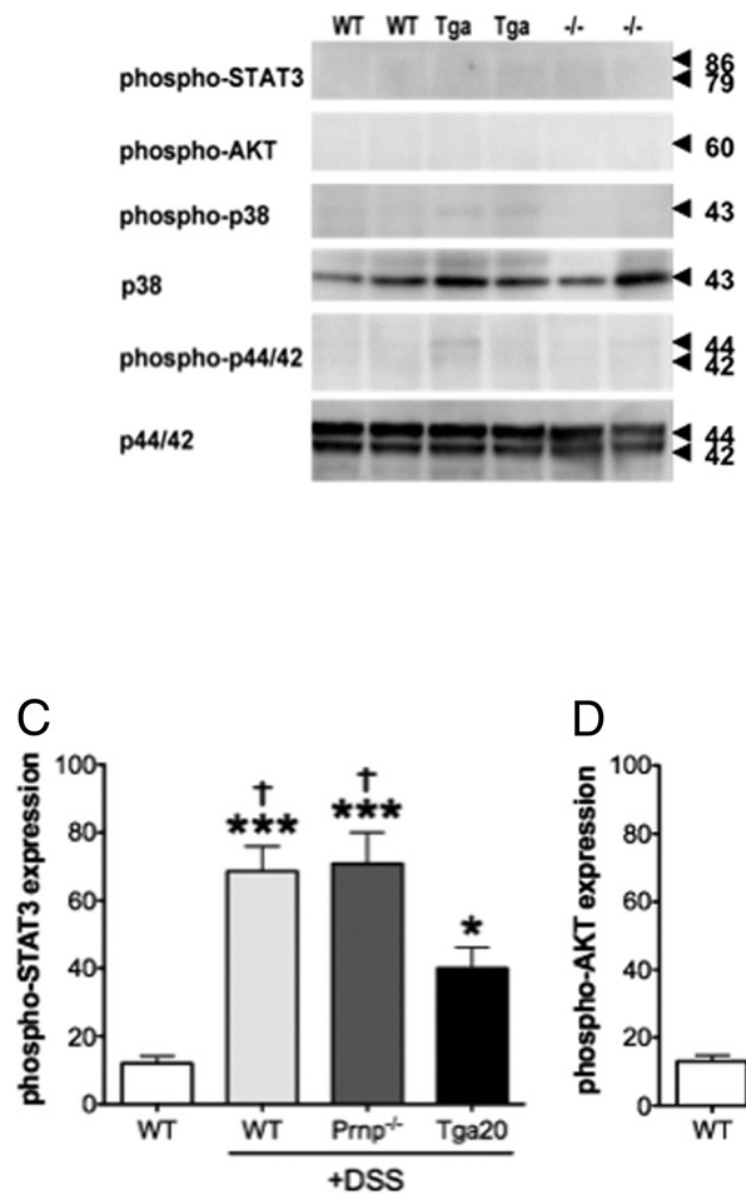

B

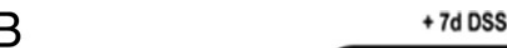

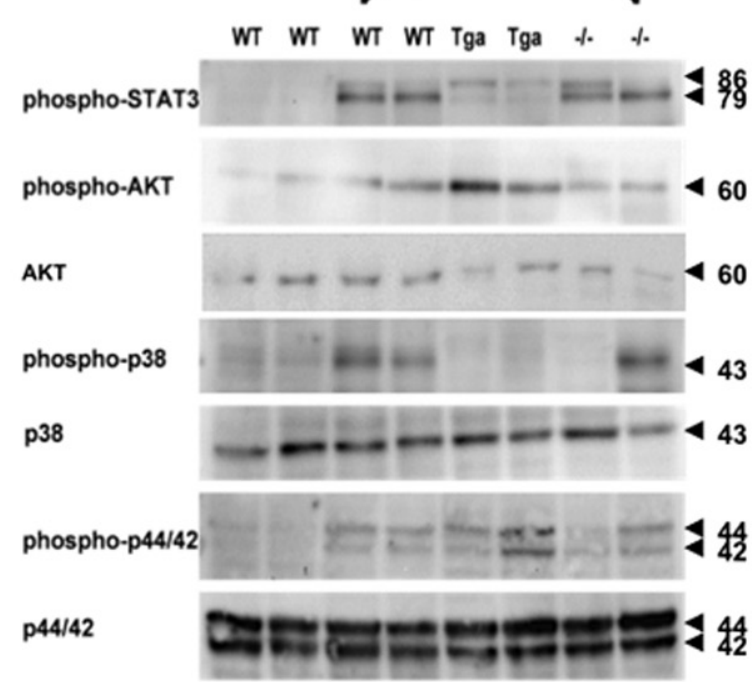

$\mathrm{E}$

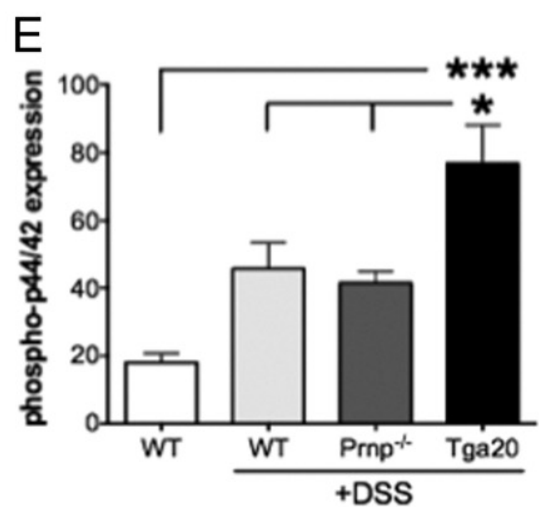

Figure 7. Effects of $\mathrm{PrP}^{\mathrm{C}}$ expression on pro-apoptotic and pro-survival factors in DSS-treated mice. A: There were no basal level differences in either pro-survival or pro-apoptotic signaling molecules among groups. B: Representative immunoblots of cell survival factors from colonic tissues of mice at 7 days after treatment with DSS. C: Colonic expression of activated STAT3 was reduced in DSS-treated Tga20 mice relative to Prnp ${ }^{-1-}$ or WT mice (* $P<0.05$ or ${ }^{*}{ }^{* * * *} P<0.001$ versus untreated WT mice; ${ }^{\dagger} P<0.01$ versus Tga20 mice). D: Phospho-Akt expression was increased in mice that overexpressed PrP ${ }^{\mathrm{C}}$ relative to all other groups $\left({ }^{* * *} P<0.001\right)$. Levels were also elevated in DSS-treated WT mice when compared with untreated control mice $\left({ }^{*} P<0.05\right)$. E: Colonic expression of activated p44/42 MAPK was also increased in Tga20 mice relative to all other groups examined $\left({ }^{*} P<0.05\right.$ versus DSS-treated WT and $P r n p^{-1-}$ mice; ${ }^{* * *} P<0.001$ versus untreated mice). Bars represent the mean \pm SE values of five or more mice.

increased $\mathrm{PrPC}^{\mathrm{C}}$ expression, we subsequently tested whether signaling molecules known to be involved in the regulation of cell survival were affected. There were no measurable differences in the colonic basal expression levels of phospho-Akt, p44/42, p38, or STAT3 among the untreated groups (Figure 7A). However, Tga20 mice that received DSS for 7 days exhibited significantly increased levels of phospho-p44/42 mitogen-activated protein kinase (MAPK) and phospho-Akt along with a trend to reduced phospho-p38 relative to similarly treated WT or Prnp ${ }^{-1-}$ mice (Figure 7, B, D, and E). Moreover, phospho-STAT3 levels were markedly reduced in the Tga20 mice when compared with either Prnp-deficient or WT mice (Figure 7C).

Given that as phospho-Akt and phospho-p44/42 MAPK, molecules involved in signal transduction pathways that promote cell survival, were elevated in the colon of DSStreated $\mathrm{PrP}^{\mathrm{C}}$ overexpressing mice, we next examined downstream apoptosis regulator proteins of the Bcl-2 family that are known to be regulated by these molecules (Figure
8A). There were no significant differences in the basal levels of anti-apoptotic Bcl-2 (Figure 8B) or pro-apoptotic Bax (Figure $8 C$ ) expression among the various groups of mice. However, in DSS-treated Prnp-deficient mice, BAD expression (Figure 8D) was significantly elevated, whereas the expression level of anti-apoptotic phospho-BAD (ser136) was reduced (Figure $8 \mathrm{~F}$ ) relative to all other groups of mice. Conversely, phospho-BAD expression levels in DSS-treated overexpressing $\mathrm{PrP}^{\mathrm{C}}$ mice, both at Ser112 (Figure 8E) and Ser136 (Figure 8F), were markedly elevated relative to the other similarly treated mice. No increase in activated caspase-3 or poly (ADP-ribose) polymerase cleavage was observed among the various DSS-treated groups (data not shown).

\section{Discussion}

Although the physiologic function(s) of $\mathrm{PrP}^{\mathrm{C}}$ remains unclear, evidence suggests that this molecule possesses 

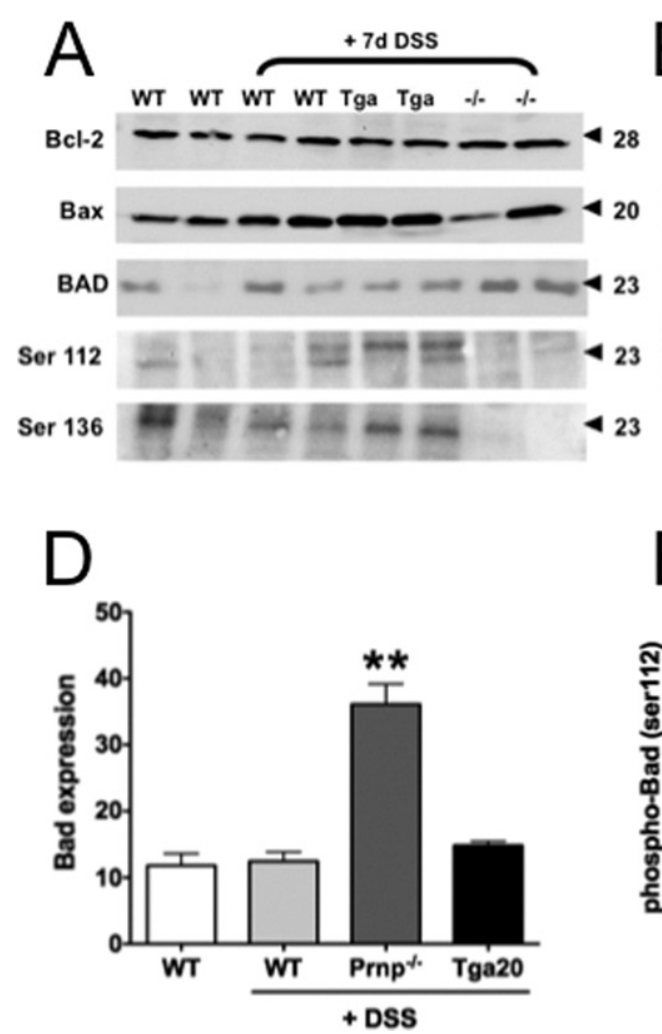
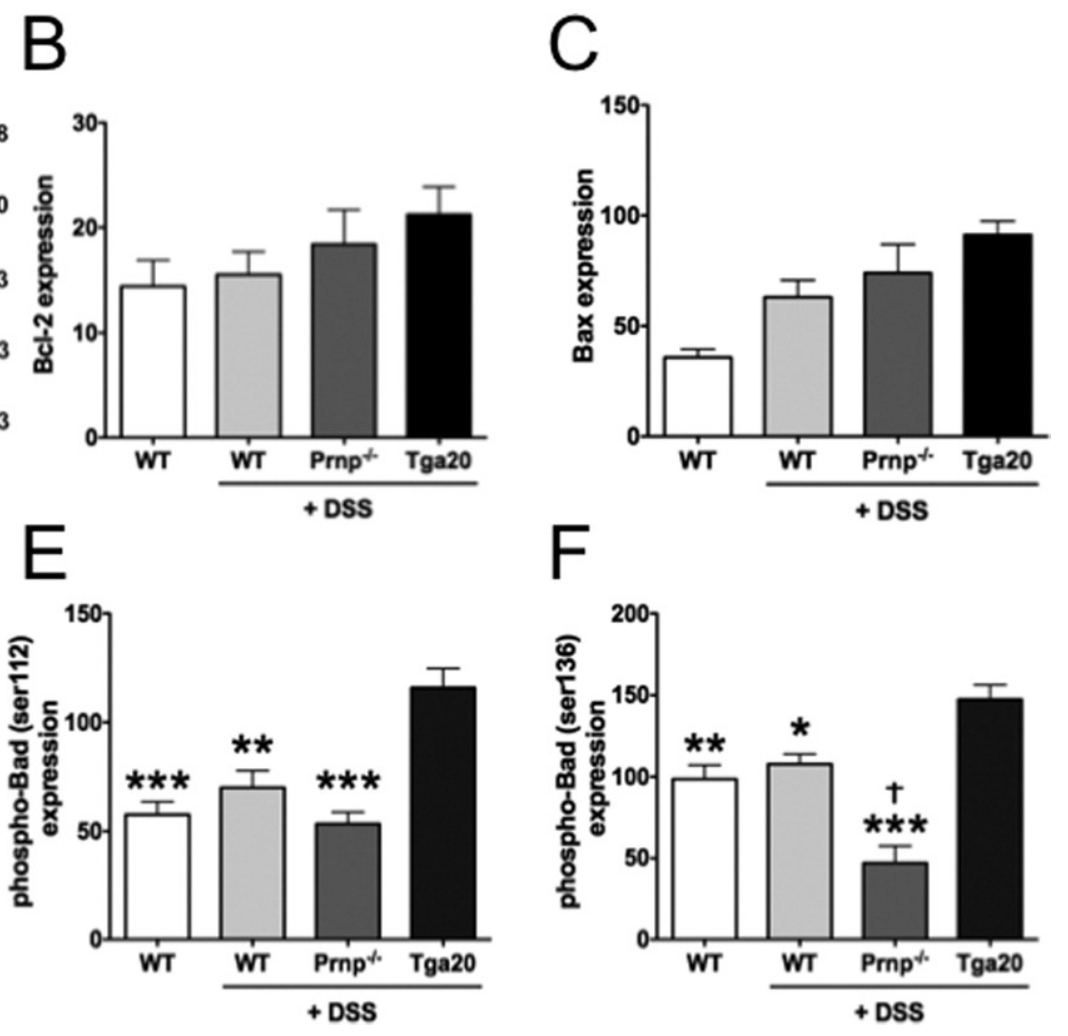

Figure 8. $\mathrm{PrP}^{\mathrm{C}}$ expression modulates apoptosis-regulating proteins during DSS-induced colitis. A: Representative immunoblots of Bcl-2 family proteins sampled from mice treated with DSS for 7 days. There were no differences in Bcl-2 (B) or Bax (C) expression among treated groups. D: Expression of BAD was significantly elevated in DSS-treated Prnp-deficient mice relative to all other groups $\left({ }^{* *} P<0.01\right)$. E and $\mathbf{F}$ : In contrast, phospho-BAD expression (at Ser112 and Ser136) in DSS-treated overexpressing $\mathrm{PrP}^{\mathrm{C}}$ mice was elevated relative to vehicle- or DSS-treated groups $\left({ }^{*} P<0.05,{ }^{* * *} P<0.01\right.$, ${ }^{* * * *} P<0.001$ versus DSS-treated Tga20 mice) The expression of Ser136 was significantly reduced in Prnp-deficient mice when compared to all groups $(* * *<<0.01)$. Bars represent the mean \pm SE values of four or more mice.

potent cytoprotective properties. ${ }^{37}$ For example, Prnpdeficient mice exhibited increased sensitivity to oxidative stress, ${ }^{3,38}$ suggesting that this protein somehow promotes antioxidant defenses that might have a role in attenuating inflammatory responses. In view of these cytoprotective properties, mice that either lacked Prnp or overexpressed $\mathrm{PrP}^{\mathrm{C}}$ were subjected to an experimental model of colitis. We observed that overexpression of $\mathrm{PrP}^{\mathrm{C}}$ provided protection against DSS-induced colitis. In contrast, mice lacking this molecule demonstrated marked elevations in several proinflammatory cytokine transcripts and pro-apoptotic regulatory proteins, factors predicted to exacerbate colitis. As reported by Sigurdson et al, ${ }^{30}$ who demonstrated increased $\mathrm{PrP}^{\mathrm{C}}$ expression in the inflamed colons of Salmonella-infected mice, we observed that DSS-induced colitis increased $\mathrm{PrP}^{\mathrm{C}}$ expression from the endogenous locus. Expression of $\operatorname{PrP}^{\mathrm{C}}$ from the Tga20 transgene was also up-regulated, which suggests that the necessary regulatory elements were present in the Prnp promoter fragment used in the vector. ${ }^{33}$ The colons of mice that overexpressed $\mathrm{PrP}^{\mathrm{C}}$ demonstrated reduced levels of proinflammatory cytokine transcripts and evidence of pro-survival signaling pathway activation. Collectively, our findings demonstrate that $\mathrm{PrP}^{\mathrm{C}}$ has previously unrecognized cytoprotective and/or anti-inflammatory properties within the gut.

$\operatorname{PrP}^{\mathrm{C}}$ deficiency exacerbates both oxidative stress and inflammation, factors that are involved in the pathogene- sis of inflammatory bowel disease. In the present study, we observed that symptoms like those of inflammatory bowel disease (ie, diarrhea, bloody stools, and weight loss) occurred earlier in Prnp ${ }^{-1-}$ and WT mice as compared to Tga20 mice. Although there were elevations in the HAI in all mice that received DSS, there were marked reductions in colonic damage indices in mice that overexpressed $\mathrm{PrP}^{\mathrm{C}}$. Moreover, microscopic examination clearly demonstrated that DSS treatment, which markedly increased DAls in $\mathrm{PrP}^{\mathrm{C}}$-deficient and WT mice, was dramatically attenuated in Tga20 mice. Moreover, DSStreated $\mathrm{PrP}^{\mathrm{C}}$-deficient mice exhibited reduced brush border membrane and goblet cell numbers relative to similarly treated WT mice.

Basal intestinal permeability, potentially affected by either the presence or absence of $\mathrm{PrP}^{\mathrm{C}}$, could have altered susceptibility to enteric bacterial invasion and, thus, exacerbated immune responses in mice lacking this molecule. Our results demonstrate that there were no differences in overall gut permeability among the various groups of mice. This was notable because it demonstrated that intestinal barrier function was not altered under normal physiologic conditions and, thus, was unlikely to be the initial factor responsible for the observed differences in disease severity.

$\mathrm{PrP}^{\mathrm{C}}$ appears to be involved in the regulation of cellular immunity. ${ }^{18,25}$ For example, the severity of murine experimental autoimmune encephalomyelitis, a model of mul- 
tiple sclerosis, was significantly increased in $\mathrm{PrP}^{\mathrm{C}}$-deficient mice, ${ }^{18,25}$ whereas overexpression of $\mathrm{PrP}^{\mathrm{C}}$ conferred protection against induction of disease. ${ }^{19}$ The increased neuroinflammation observed in $\mathrm{PrPC}^{\mathrm{C}}$ deficiency was attributed to the presence of increased levels of IL-17-producing T cells. ${ }^{18,25}$ These observations are interesting in the context of the present study because the cytokine expression profile in the mice lacking Prnp, together with the marked increase in phospho-STAT3, a molecule required for the ontogeny of Th17 cells, would be predicted to favor Th17 cell differentiation. This is of interest because transcripts for Th17-related cytokines are increased in particular in ulcerative colitis, and to a lesser degree in Crohn's disease. ${ }^{39}$ Furthermore, IL-17A expression is increased in the intestinal mucosa of patients with inflammatory bowel disease, and although controversial, there are indications that Th17-driven immune responses may be involved in the pathogenesis of inflammatory bowel disease. ${ }^{28,40}$

The IL-6/gp130/STAT3 pathway promotes disease progression by promoting cytokine and growth factor production, hyperplasia, and fibrosis, ${ }^{24}$ whereas SOCS3 is part of the JAK/STAT negative feedback loop in which SOCS3 acts to suppress STAT3-modulated inflammatory reactions driven by cytokines of the IL-6-family. ${ }^{41}$ Furthermore, increased phospho-STAT3 and SOCS3 levels have been detected in mice with experimental ileitis ${ }^{42}$ and in patients with ulcerative colitis or active Crohn's disease. ${ }^{24}$ We observed that phospho-STAT3 levels were markedly reduced in Tga20 mice as compared with either Prnp-deficient or WT mice. This is significant because genome-wide association studies have indicated that the gene encoding STAT3, a factor involved in Th17 differentiation, is associated with susceptibility to inflammatory bowel disease. ${ }^{43}$ We also observed that SOCS3 expression was attenuated in mice that overexpressed $\mathrm{PrP}^{\mathrm{C}}$ when compared with the other DSS-treated groups. This finding was consistent with the observation that DSStreated Tga20 mice exhibited diminished IL-6 transcript levels and STAT3 activation.

The anti-inflammatory cytokines IL-4 and IL-10 may also have a role in prion diseases, inasmuch as it has been recently demonstrated that IL-10-deficient mice are highly predisposed to prion disease development and reduced incubation times. ${ }^{44}$ Conversely, Stoeck et $\mathrm{a}^{45}$ demonstrated that IL-10 was significantly elevated in the cerebrospinal fluid in patients with variant CreutzfeldtJakob disease and in patients with various other neurodegenerative diseases. In the present study, although $\mathrm{DAI}, \mathrm{HAl}$, and proinflammatory cytokine production was increased in Prnp ${ }^{-\prime-}$ mice, there was also an increase in $\mathrm{IL}-10$ expression above that seen in all other DSS-treated groups. This was likely the result of the increased inflammation present in the colon of these animals and the ability of macrophage-derived IL-10 to act as a counterregulatory measure during inflammation.

Because the presence or absence of $\mathrm{PrP}^{\mathrm{C}}$ has the potential to affect various cell-signaling pathways such as the phosphatidylinositol 3-kinase-Akt axis, ${ }^{7,15}$ we examined signal transduction molecules known to be involved in the regulation of cell survival. Within the colon of the Tga20 mice, we observed significant elevations in phospho-p44/42 MAPK and Akt, and a trend toward a decreased level of phospho-p38 in response to DSS as compared with treated WT or Prnp ${ }^{-1-}$ mice. This was interesting in view of reports that $\operatorname{PrP}^{C}$ seems to be involved in the activation of p44/42 MAPK and Akt during macrophage phagocytosis. ${ }^{26,27}$ Hence, modulation of macrophage p44/42 MAPK and Akt by $\operatorname{PrP}^{\mathrm{C}}$ might be of significance in colitis. The higher levels of pro-survival molecules such as phospho-Akt in the inflamed colons of Tga20 mice were consistent with previous observations of phosphatidylinositol 3-kinase pathway activity regulation by $\operatorname{PrP}^{\mathrm{C} 7,15}$ and could account, at least in part, for the milder colonic disease manifested by these $\mathrm{PrP}^{\mathrm{C}}$ overexpressing animals.

A frequently cited cellular function of $\operatorname{PrP}^{C}$ is its survivalpromoting effect on neuronal and non-neuronal cells. These protective functions are reportedly mediated by the anti-apoptotic or anti-oxidative properties of PrPC; however, relatively little is known about the proximal mechanisms responsible for these effects. ${ }^{46}$ We observed that phospho-Akt and phospho-p44/42 MAPK levels were markedly increased in mice that overexpressed $\mathrm{PrP}^{\mathrm{C}}$. Increased levels of either of these signaling molecules leads to the phoshorylation of BAD, at either Ser112 (by p44/42) ${ }^{47}$ or Ser136 (by pAkt). ${ }^{48}$ Phosphorylation initiates $B A D$ homodimerization, which in turn would leave $\mathrm{Bcl}-2$ free to inhibit Bax-triggered apoptosis. ${ }^{49}$ Thus, Akt or p44/42 MAPK-induced phosphorylation of BAD, as we observed in the colons of $\mathrm{PrPC}^{\mathrm{C}}$ overexpressing mice, may well have promoted cell survival. In contrast, dephosphorylated $\mathrm{BAD}$, which heterodimerizes with $\mathrm{Bcl}-2,{ }^{49}$ could effectively counteract the protective effects of $\mathrm{Bcl}-2$ and, hence, promote cell death. Increased levels of dephosphorylated BAD, as were observed in the colons of DSStreated Prnp ${ }^{-1-}$ mice, may have promoted $\mathrm{BAD} / \mathrm{Bcl}-2$ heterodimerization, thus attenuating the anti-apoptotic ability of $\mathrm{Bcl}-2$. However, we detected no evidence of activated caspase-3 or cleaved poly (ADP-ribose) polymerase in DSS-treated colonic tissues. Perhaps a longer term model of colitis would reveal differences in the levels of apoptotic cells between the various genotypes.

In the gut, we and others have observed that the cells of the enteric nervous system, the proliferation of which increases during intestinal inflammation, ${ }^{50}$ express high levels of immunoreactive PrPC ${ }^{11}$ In view of the ability of enteric glial cells to produce IL-6, ${ }^{51}$ these cells may have provided an additional source of this cytokine. In addition, transcripts encoding IL-1 $\beta$ and IL-6, which were increased during DSS-induced colitis, have been shown to regulate cytokine production by enteric glial cells. ${ }^{51}$ Although no differences were observed in basal intestinal permeability to FITC-conjugated dextran, the possibility remains that permeability differences might be present under inflammatory conditions.

It has been proposed that $\operatorname{PrP}^{\mathrm{C}}$ may function as an antimicrobial peptide. One characteristic of antimicrobial peptides is that they have cationic peptide motifs (hence they are also called cationic antimicrobial peptides) and heparin-binding peptide sequences that enable them to act on both gram-positive and gram-negative bacteria. ${ }^{52}$ 
Because $\mathrm{PrP}^{\mathrm{C}}$ has exposed cationic and heparin-binding regions at the $\mathrm{N}$-terminus, this molecule has been proposed as antimicrobial peptide candidate. Indeed, Pasupuleti et $\mathrm{al}^{29}$ have demonstrated that both intact $\operatorname{PrP}^{\mathrm{C}}$ and $\mathrm{N}$-terminal peptides derived from this molecule exerted membrane-disrupting effects on bacteria similar to those observed with the human antimicrobial peptide LL-37. Thus, if $\mathrm{PrP}^{\mathrm{C}}$ were functioning as an antimicrobial peptide, it might, at least in part, account for the attenuation of colitis in Tga20 mice.

In conclusion, while overexpression of $\mathrm{PrP}^{\mathrm{C}}$ greatly attenuated DSS-induced colitis, mice lacking this molecule experienced more severe clinical disease, accompanied by increased expression of several transcripts encoding proinflammatory cytokines and changes in cellsignaling factors. In contrast, $\mathrm{PrP}^{\mathrm{C}}$ overexpression was associated with reduction in proinflammatory cytokine levels and the up-regulation of pro-survival pathways. Our results are of potential relevance in human inflammatory bowel disease, given the interindividual and interspecies variations observed in $\operatorname{PrPC}^{C}$ expression. ${ }^{53-56}$ In addition, multiple polymorphic sites in human PRNP could potentially affect the function of this molecule. ${ }^{57}$ Thus, in the context of inflammatory bowel disease, variations in PRNP or sequence might plausibly have a modulating effect on disease susceptibility or clinical course.

\section{Acknowledgments}

We thank Dr. Susan Lindquist (Massachusetts Institute of Technology) for providing the Tga20 mice and Michelle Villemaire and Garnet Walker for genotyping and maintenance of the animals used in this study.

\section{References}

1. Bueler $\mathrm{H}$, Fischer M, Lang $\mathrm{Y}$, Bluethmann H, Lipp HP, DeArmond SJ, Prusiner SB, Aguet M, Weissmann C: Normal development and behaviour of mice lacking the neuronal cell-surface PrP protein. Nature 1992, 356:577-582

2. Collinge J, Whittington MA, Sidle KC, Smith CJ, Palmer MS, Clarke AR, Jefferys JG: Prion protein is necessary for normal synaptic function. Nature 1994, 370:295-297

3. Kuwahara C, Takeuchi AM, Nishimura T, Haraguchi K, Kubosaki A, Matsumoto Y, Saeki K, Yokoyama T, Itohara S, Onodera T: Prions prevent neuronal cell-line death. Nature 1999, 400:225-226

4. Aguzzi A, Polymenidou M: Mammalian prion biology: one century of evolving concepts. Cell 2004, 116:313-327

5. Schatzl HM, Da Costa M, Taylor L, Cohen FE, Prusiner SB: Prion protein gene variation among primates. J Mol Biol 1995, 245:362-374

6. Vassallo N, Herms J: Cellular prion protein function in copper homeostasis and redox signalling at the synapse. J Neurochem 2003, 86: 538-544

7. Vassallo N, Herms J, Behrens C, Krebs B, Saeki K, Onodera T, Windl $\mathrm{O}$, Kretzschmar HA: Activation of phosphatidylinositol 3-kinase by cellular prion protein and its role in cell survival. Biochem Biophys Res Commun 2005, 332:75-82

8. Mouillet-Richard S, Ermonval M, Chebassier C, Laplanche JL, Lehmann S, Launay JM, Kellermann O: Signal transduction through prion protein. Science 2000, 289:1925-1928

9. Schneider B, Mutel V, Pietri M, Ermonval M, Mouillet-Richard S, Kellermann O: NADPH oxidase and extracellular regulated kinases $1 / 2$ are targets of prion protein signaling in neuronal and nonneuronal cells. Proc Natl Acad Sci USA 2003, 100:13326-13331
10. Ford MJ, Burton LJ, Morris RJ, Hall SM: Selective expression of prion protein in peripheral tissues of the adult mouse. Neuroscience 2002, 113:177-192

11. Shmakov AN, McLennan NF, McBride P, Farquhar CF, Bode J, Rennison KA, Ghosh S: Cellular prion protein is expressed in the human enteric nervous system. Nat Med 2000, 6:840-841

12. Heggebo R, Press CM, Gunnes G, Lie KI, Tranulis MA, Ulvund M, Groschup MH, Landsverk T: Distribution of prion protein in the ileal Peyer's patch of scrapie-free lambs and lambs naturally and experimentally exposed to the scrapie agent. J Gen Virol 2000, 81:23272337

13. Morel E, Fouquet $S$, Chateau D, Yvernault L, Frobert $Y$, PinconRaymond M, Chambaz J, Pillot T, Rousset M: The cellular prion protein PrPc is expressed in human enterocytes in cell-cell junctional domains. J Biol Chem 2004, 279:1499-1505

14. Marciano PG, Brettschneider J, Manduchi E, Davis JE, Eastman S, Raghupathi R, Saatman KE, Speed TP, Stoeckert CJ Jr, Eberwine JH, McIntosh TK: Neuron-specific mRNA complexity responses during hippocampal apoptosis after traumatic brain injury. J Neurosci 2004, 24:2866-2876

15. Weise J, Sandau R, Schwarting S, Crome O, Wrede A, SchulzSchaeffer W, Zerr I, Bahr M: Deletion of cellular prion protein results in reduced Akt activation, enhanced postischemic caspase-3 activation, and exacerbation of ischemic brain injury. Stroke 2006, 37 : $1296-1300$

16. Calella AM, Farinelli M, Nuvolone M, Mirante O, Moos R, Falsig J, Mansuy IM, Aguzzi A: Prion protein and Abeta-related synaptic toxicity impairment. EMBO Mol Med 2010, 8:306-314

17. Lauren J, Gimbel DA, Nygaard HB, Gilbert JW, Strittmatter SM: CelIular prion protein mediates impairment of synaptic plasticity by amyloid-beta oligomers. Nature 2009, 457:1128-1132

18. Tsutsui S, Hahn JN, Johnson TA, Ali Z, Jirik FR: Absence of the cellular prion protein exacerbates and prolongs neuroinflammation in experimental autoimmune encephalomyelitis. Am J Pathol 2008, 173: 1029-1041

19. Hu W, Nessler S, Hemmer B, Eagar TN, Kane LP, Leliveld SR, Muller-Schiffmann A, Gocke AR, Lovett-Racke A, Ben LH, Hussain RZ, Breil A, Elliott JL, Puttaparthi K, Cravens PD, Singh MP, Petsch B, Stitz L, Racke MK, Korth C, Stuve O: Pharmacological prion protein silencing accelerates central nervous system autoimmune disease via T cell receptor signalling. Brain 2010, 133:375-388

20. Singh A, Kong Q, Luo X, Petersen RB, Meyerson H, Singh N: Prion protein (PrP) knock-out mice show altered iron metabolism: a functional role for PrP in iron uptake and transport. PLoS One 2009, 4:e6115

21. Brown DR: Brain proteins that mind metals: a neurodegenerative perspective. Dalton Trans 2009, (21):4069-4076

22. Watt NT, Taylor DR, Gillott A, Thomas DA, Perera WS, Hooper NM: Reactive oxygen species-mediated beta-cleavage of the prion protein in the cellular response to oxidative stress. J Biol Chem 2005, 280:35914-35921

23. Xavier RJ, Podolsky DK: Unravelling the pathogenesis of inflammatory bowel disease. Nature 2007, 448:427-434

24. Li Y, de Haar C, Chen M, Deuring J, Gerrits MM, Smits R, Xia B, Kuipers EJ, van der Woude CJ: Disease-related expression of the IL6/STAT3/SOCS3 signalling pathway in ulcerative colitis and ulcerative colitis-related carcinogenesis. Gut 2010, 59:227-235

25. Ingram RJ, Isaacs JD, Kaur G, Lowther DE, Reynolds CJ, Boyton RJ, Collinge J, Jackson GS, Altmann DM: A role of cellular prion protein in programming T-cell cytokine responses in disease. FASEB J 2009 23:1672-1684

26. Krebs B, Dorner-Ciossek C, Schmalzbauer R, Vassallo N, Herms J, Kretzschmar HA: Prion protein induced signaling cascades in monocytes. Biochem Biophys Res Commun 2006, 340:13-22

27. de Almeida CJ, Chiarini LB, da Silva JP, E Silva PM, Martins MA, Linden R: The cellular prion protein modulates phagocytosis and inflammatory response. J Leukoc Biol 2005, 77:238-246

28. Eastaff-Leung N, Mabarrack N, Barbour A, Cummins A, Barry S: Foxp3+ regulatory T cells: Th17 effector cells, and cytokine environment in inflammatory bowel disease. J Clin Immunol 2010, 30:80-89

29. Pasupuleti M, Roupe M, Rydengard V, Surewicz K, Surewicz WK, Chalupka A, Malmsten M, Sorensen OE, Schmidtchen A: Antimicrobial activity of human prion protein is mediated by its $\mathrm{N}$-terminal region. PLoS One 2009, 4:e7358 
30. Sigurdson CJ, Heikenwalder M, Manco G, Barthel M, Schwarz P, Stecher B, Krautler NJ, Hardt WD, Seifert B, MacPherson AJ, Corthesy I, Aguzzi A: Bacterial colitis increases susceptibility to oral prion disease. J Infect Dis 2009, 199:243-252

31. Strober W, Fuss IJ, Blumberg RS: The immunology of mucosal models of inflammation. Annu Rev Immunol 2002, 20:495-549

32. Wirtz S, Neufert C, Weigmann B, Neurath MF: Chemically induced mouse models of intestinal inflammation. Nat Protoc 2007, 2:541-546

33. Fischer M, Rulicke T, Raeber A, Sailer A, Moser M, Oesch B, Brandner S, Aguzzi A, Weissmann C: Prion protein (PrP) with amino-proximal deletions restoring susceptibility of PrP knockout mice to scrapie. EMBO J 1996, 15:1255-1264

34. Cooper HS, Murthy SN, Shah RS, Sedergran DJ: Clinicopathologic study of dextran sulfate sodium experimental murine colitis. Lab Invest 1993, 69:238-249

35. Kiela PR, Laubitz D, Larmonier CB, Midura-Kiela MT, Lipko MA, Janikashvili N, Bai A, Thurston R, Ghishan FK: Changes in mucosal homeostasis predispose NHE3 knockout mice to increased susceptibility to DSS-induced epithelial injury. Gastroenterology 2009, 137: 965-975, 975 e961-e910

36. Marcos Z, Pffeifer K, Bodegas ME, Sesma MP, Guembe L: Cellular prion protein is expressed in a subset of neuroendocrine cells of the rat gastrointestinal tract. J Histochem Cytochem 2004, 52:1357-1365

37. Roucou X, LeBlanc AC: Cellular prion protein neuroprotective function: implications in prion diseases. J Mol Med 2005, 83:3-11

38. Bounhar $Y$, Zhang Y, Goodyer CG, LeBlanc A: Prion protein protects human neurons against Bax-mediated apoptosis. J Biol Chem 2001 276:39145-39149

39. Kobayashi T, Okamoto S, Hisamatsu T, Kamada N, Chinen H, Saito R, Kitazume MT, Nakazawa A, Sugita A, Koganei K, Isobe K, Hibi T: IL23 differentially regulates the Th1/Th17 balance in ulcerative colitis and Crohn's disease. Gut 2008, 57:1682-1689

40. Fujino S, Andoh A, Bamba S, Ogawa A, Hata K, Araki Y, Bamba T, Fujiyama $Y$ : Increased expression of interleukin 17 in inflammatory bowel disease. Gut 2003, 52:65-70

41. Suzuki A, Hanada T, Mitsuyama K, Yoshida T, Kamizono S, Hoshino T, Kubo M, Yamashita A, Okabe M, Takeda K, Akira S, Matsumoto S, Toyonaga A, Sata M, Yoshimura A: CIS3/SOCS3/SSI3 plays a negative regulatory role in STAT3 activation and intestinal inflammation. J Exp Med 2001, 193:471-481

42. Mitsuyama K, Matsumoto S, Rose-John S, Suzuki A, Hara T, Tomiyasu N, Handa K, Tsuruta O, Funabashi H, Scheller J, Toyonaga A, Sata M: STAT3 activation via interleukin 6 trans-signalling contributes to ileitis in SAMP1/Yit mice. Gut 2006, 55:1263-1269

43. Brand S: Crohn's disease: Th1, Th17 or both? The change of a paradigm: new immunological and genetic insights implicate Th17 cells in the pathogenesis of Crohn's disease. Gut 2009, 58:1152-1167

44. Thackray AM, McKenzie AN, Klein MA, Lauder A, Bujdoso R: Accelerated prion disease in the absence of interleukin-10. J Virol 2004 78:13697-13707

45. Stoeck K, Bodemer M, Ciesielczyk B, Meissner B, Bartl M, Heinemann $U$, Zerr I: Interleukin 4 and interleukin 10 levels are elevated in the cerebrospinal fluid of patients with Creutzfeldt-Jakob disease. Arch Neurol 2005, 62:1591-1594

46. Aguzzi A, Baumann F, Bremer J: The prion's elusive reason for being. Annu Rev Neurosci 2008, 31:439-477

47. Zha J, Harada H, Yang E, Jockel J, Korsmeyer SJ: Serine phosphorylation of death agonist BAD in response to survival factor results in binding to 14-3-3 not BCL-X(L). Cell 1996, 87:619-628

48. Datta SR, Dudek H, Tao X, Masters S, Fu H, Gotoh Y, Greenberg ME: Akt phosphorylation of BAD couples survival signals to the cellintrinsic death machinery. Cell 1997, 91:231-241

49. Chao DT, Korsmeyer SJ: BCL-2 family: regulators of cell death. Annu Rev Immunol 1998, 16:395-419

50. Bradley JS Jr, Parr EJ, Sharkey KA: Effects of inflammation on cell proliferation in the myenteric plexus of the guinea-pig ileum. Cell Tissue Res 1997, 289:455-461

51. Ruhl A, Franzke S, Collins SM, Stremmel W: Interleukin-6 expression and regulation in rat enteric glial cells. Am J Physiol Gastrointest Liver Physiol 2001, 280:G1163-G1171

52. Hancock RE, Diamond G: The role of cationic antimicrobial peptides in innate host defenses. Trends Microbiol 2000, 8:402-410

53. Whitney AR, Diehn M, Popper SJ, Alizadeh AA, Boldrick JC, Relman DA, Brown PO: Individuality and variation in gene expression patterns in human blood. Proc Natl Acad Sci USA: 2003, 100:1896-1901

54. Laffont-Proust I, Faucheux BA, Hassig R, Sazdovitch V, Simon S, Grassi J, Hauw JJ, Moya KL, Haik S: The N-terminal cleavage of cellular prion protein in the human brain. FEBS Lett 2005, 579:63336337

55. Weis S, Haybaeck J, Dulay JR, Llenos IC: Expression of cellular prion protein $(\operatorname{Pr}(\mathrm{c}))$ in schizophrenia, bipolar disorder, and depression. J Neural Transm 2008, 115:761-771

56. Wopfner F, Weidenhofer G, Schneider R, von Brunn A, Gilch S, Schwarz TF, Werner T, Schatzl HM: Analysis of 27 mammalian and 9 avian PrPs reveals high conservation of flexible regions of the prion protein. J Mol Biol 1999, 289:1163-1178

57. Bishop MT, Pennington C, Heath CA, Will RG, Knight RS: PRNP variation in UK sporadic and variant Creutzfeldt-Jakob disease highlights genetic risk factors and a novel non-synonymous polymorphism. BMC Med Genet 2009, 10:146 